\title{
元気な食品小売店に学ぶ，売れない時代 の販売戦略
}

消費者との接点に立つ小売店の販売状況について解説をお願いした。地域に密着した専門小売店の状況は 大変厳しい時期が続いている。その中で, スーパーやコンビニエンスストアと異なる販売戦略で「元気のい い地域小売店」の状況を,「優良経営食料品小売店頭表彰事業（全国コンクール）」を通して, 具体的に見て いく。その結果, 消費者と「きずなづくり」に欠かせない経営観が見えてくるが, 個別の例の中から共通し て見えてくるポイントを提示していただいた。当誌の読者の多くがメーカー側の立場におられると思うが, 消費者に直接サービスを提供する立場をより理解することにより,「元気のいい地域小売店」へのメーカー 側の販売戦略に参考になると考える。

\section{小山周 三}

\section{はじめに}

小売業の販売不振が続いている。好調なのはコンビ ニエンスストア, ホームセンター, ドラッグストアな どの一部の業態だけで, 百貨店や総合スーパーなどの 大型店業態も，バブル崩壊を起点に長期淍落傾向を止 めることが出来てない。

地域に密着した専門小売店の販売不振はそれ以上に 厳しく，1972 年を成長のピークに，約 40 年間に亘っ て，店舗数，販売額を減少させてきた。とりわけ大型 店を除く専門食品小売店の減少化に歯止めがかからず, 地域小売店の抜本的な生き残り策を再検討せざるを得 ない深刻な状況が続いている。

こうした状況の中で，農林水産省の外郭団体「財団 法人 食品流通構造改善促進機構」が毎年,「優良経 営食料品小売店等表彰事業（全国コンクール）」を実 施し続けている（注 1)。今年の受賞式も平成 24 年 2 月に行われたが，通算 35 回目に当たる，長い歴史の ある表彰事業の一つである（注 2)。筆者が本コンク ールの審査委員長の委嘱を受けたのが 2001 年実施の 大会で，以来，本年大会までの 11 年間にわたり，深 刻な状況下にあるにも拘らず，家族経営を中心にしな
がらも, 優良経営食品小売店としての存在感のある貴 重な経営手法に数多く触れる機会を得てきた。

募集対象は生鮮食品小売店, 特定加工食品小売店 (酒類, 牛乳, 米穀, 菓子・パン等), 商店街の 3 つの 分野の中から優良経営店候補を発掘し, その経営ノウ ハウを共有することによって, 食品小売業の経営構造 改革につなげようという意図からの表彰制度である。

したがって, 本稿で取り挙げる事例の殆どが上記コ ンクールで農林水産大臣賞を受賞し, その経営手法が 高く評価された小売店で, 毎年冊子となって発行され ている「経営ノウハウ集 (受賞店の概要)」（注 3）を 基に, 筆者の個人的感想を加えて, 食品小売業経営の あり方を示したものである。

地域に根を張り, 顔の見える顧客の期待に応えてい る地域小売店の努力の中に, 大型店にはまねの出来な い, 家族経営店という独自のビジネスモデルの萌芽を 予感している。

\section{1. 小売業の構造変動に巻き込まれた地域小売業}

過去, 35 年間で日本の小売店の総数は, 172 万店か ら 114 万店へと 56 万店減少し, ピーク時の約 3 分の 2 に低下した。2002 年から 2007 年の直近の 5 年間で

Family Food Retailer's Strategy

Shuzo Koyama (Senior Professor of Seibu Bunri Univercity) 
は 16 万店も減少した（注 4）。年間当たりの消滅店舗 は約 3 万 2 千店埔にも及ぶ。その大部分が中小規模の 一般・専門小売店である。消滅原因として様々な要因 が考えられるが，「大型店との競争に敗れた」という 見方が一般的である。消費者が利便性の高い大型店で の買い物を優先した結果，もともと身近にあった地域 小売店での買い物を敬遠したということになる。

流通構造の激しい変革の中で大型店優位の時代が長 く続いてきた。しかしながら大型店内部の構造も大き く変化した。2000 年を境にした大型店内部の変化を レビューしておく。

1960 年代から始まった日本の流通革命を最初にリ ードしたのは「総合スーパー」であった。百貨店に次 ぐ販売シェアを確保するや否や, 百貨店を追い越し, 大型店としての不動の地位を占めるようになった。し かし，不動の地位を続けると思われた総合スーパーが 大きく失速するという事態が現れた。現在の総合スー パーの販売シェア（全小売販売額に占める割合, 2007 年調査）は $5.5 \%$ にで低下している。 $5.7 \%$ の販売シ エアの百貨店の低落傾向も止まらず, 30 坪足らずの 小型コンビニエンスストアの総売上高に並ばれ (5.2\%), 2008 年には追い越されるという屈辱を味わ った。

このような状況のなかで, 総合スーパーも, 百貨店 も，日常生活の必需品である食品販売に力を入れてお り, 総合スーパーで $52.6 \%$, 百貨店 $25.5 \%$ と販売構 成比率を高めている。中小食品店の販売機会を奪う要 因につながっていると言える。

総合スーパーに代わって, 衣・食・住の各分野での 「専門スーパー」の販売シェアが拡大した $(17.7 \%) 。$ 食品スーパー, 衣料スーパー, ホームセンター, ドラ ッグストアなどの専門スーパー業態の勢いが増してい る。ホームセンターやドラッグストアでも, 食品の販 売比率が高まり，一般食品店の形勢はますます不利の 状況下に置かれるようになった。

一般の食品小売店の存在にとって最も大きな打撃を 与えたのは,「コンビニエンスストアの躍進」であっ たかもしれない。かつて「小売業の王様」と呼ばれた 百貨店を追い抜く存在にまで成長した。コンビニエン スストアの店舗数 (約 4.2 万), 従業員数 (約 130 万 人), 来店客数（年間約 132.8 億人）を擁する，日常 生活に欠かせない「社会インフラ」となっている（注
$5)$ 。

零細過多と表現されてきた日本の地域小売店は, コ ンビニエンスストアが台頭する 1970 年頃までは, 地 域の日常生活に欠かせない社会インフラの役割を担っ てきていた。その役割を総合スーパーに, そして食品 スーパーに奪われ, さらにはコンビニエンスストアに 取って代わられてしまっている。地域小売店も,「あ の店が在って良かった」と言われる存在性を追及する 工夫が果たしてできないものなのかどうか。

インターネットの普及と共に, ノンストア・リテイ リングの可能性が大きく開かれた。「ネット販売」が, スーパー,コンビニエンスストアに次ぐ「第三の流通 革命」として登場している。店頭販売が持つ負の限界, 営業時間，来店距離の制約を超越した販売革命をネッ 卜販売がもたらしている。あとで紹介する優良経営食 品店は, 店頭売りだけでなく, ネット販売でも健闘し, 新たな販路拡大 $=$ 顧客開拓を図っている。

小売業は「変化適応産業」と呼ばれてきた。これは, 大型店だけに当てはまるのではなく, 一般小売店にも 適応されなければならない。「売れない時代」とは, 「変化への不適応」を表すこと言葉であって, 積極的 に環境変化に立ち向かい, 売れる状況を創りだす努力 を重ねる地域密着型繁盛店の販売戦略からの示唆を受 け止める必要がある。

\section{2. 元気のいい地域小売店の存在から学ぶ}

「大型店は怖くない」。景気低迷, 大型店攻勢など, 逆風に立ち向かいながら, 元気に頑張っている地域食 品小売店が口にする言葉である。「怖くない」という 言い方は少し誇張した言い方かも知れないが,「大型 店ではやれないことをやれば自分達の存在感がある」 という意味を含んでいる。

確かに, 大型店やチェーンストアと同じ商売のやり 方をしたのでは，独立小売店は競争に勝てない。大型 店に出来ない売り方, 品揃えの絞り方, 提案の仕方な どに工夫を凝らせば, 独自の存在感を消費者に認めて 貴うことは出来る。家族経営の一番の強さは「チーム ワークカ」にあり, 親子, 夫婦, 兄弟などが上手く役 割分担すれば, 最強の販売チームを造り出すことがで きる。商店主の奥様の上手な薦め方などは, セルフサ ービス方式の販売では絶対にまねが出来ない。

大型店やチェーン店には出来ない（ないしは出来そ 
うにない）売り方として次のようなやり方がある。

第一は「目利き力」の違いである。酒屋であれば, 全国の蔵元を訪ね, 自分の舌で確かめた上でのおいし い酒を集めてくるこだわり，肉屋であれば，ブランド 産の牛肉, 米屋であれば用途や好みに合せた十人十色 のニーズに対応できる米のラインナップなど，おしい もの，いいものへの徹底したこだわりが，大型店には 出来ない自信を生み出している。商品力は小売店の生 命線であり，目利き力によって，個性ある品揃えが実 現できれば，大型店との違いを前面に押し出すことが 出来る。

第二は「手間をかける販売」での付加価値提供で, 大型店との違いを顧客に分かって貴う販売戦略の実践 である。大型店の販売戦略が「手抜き商法」にある。 多少, 誤解を受けるかもしれないが, 標準化, 単純化 して, 手間隙を省かないとチェーンのシステムに乗ら ない売り方が大型店である。単独店が同じ土俵で競争 したら不利になるのは明らかである。出来るだけ手を かけた商品づくり, 売り方に付加価值を付ければ, 固 定客がついてきてくれるやり方地域小売店は実践して いる。

第三は「対話力」の活用である。セルフ販売の逆は 対面販売である。対面販売の本当の良さは「対話力」 にあるといえる。商品力はその良さを伝える「説得 力」が伴って, 初めて本来の価值が生まれる。スーパ 一やコンビニエンスストアでは, 原則, 何の商品説明 もなしに売られるのが当たり前になってしまっている が, 説明力不足が販売不振の理由の一つになっていな いか。個人商店の強みは, 本物価值, 使用価値を一生 懸命に顧客に伝える伝達力・コミュニケーション力に あることを繁盛店が教えてくれている。

第四は「鮮度・季節感」を常に意識した販売戦略を 展開していることである。全ての食べ物が量産可能に なる中で，季節性が無くなり（あるいは薄れる），い つでも食べられる，いわゆる通年化してしまっている。 非常に便利で恵まれた食生活が常態化した。スーパー の発展がもたらした食生活革命ともいえるが，この時 期しか出会えない食べ物との感動などが減退したこと も事実である。このような感動や驚きのような価值の 提供は, 対話力のある小売店だからこそ展開できる魅 力かもしれない。12 ケ月をカレンダー化し, 季節感 と旬の味わいを提案する販売戦略で, 顧客を飽きさせ
ない提案力こそ, 真の商いの道であるというべきであ る。

消費不振の理由として「消費者はモノを買わなくな った」という見方が必ず出てくる。本当に買わなくな ったのか，それとも買う気を起こさせるような「存在 感ある店」が少なくなってしまったのか。私は後者の 考え方を採用したい。「売れない」ことを消費者のせ いにするのではなく, むしろ「売ってない」という販 売力不足を問題にするべきであろう。

「売る」ということは「買い手の共感を得る」とい うことである。買い手の共感が得られるような売り方 が大事であって, そのためには, 売る人の魅力も大事 な共感要素になってくる。売る人のもてなし力, 説得 力, 人間力が存在感ある小売業には欠かせない。

\section{3.「不況に負けない」元気な小売店の事例紹介}

事例 1. 有限会社 肉のたかさご（東京都中央区佃）

「やき豚で一躍脚光を集めた下町の肉店」

地下鉄有楽町線・月島駅から徒歩 2 分程の大通りに 面した小さな肉屋さん。どこにもある，良く見かける タイプの肉屋さん。約 10 坪の小さなお店であるが, 「肉のたかさご」という大きな看板が目立つ。拈店の 前は, 何か劇場前といった䨌囲気が漂う, 何かが始ま るといった期待感を顧客に感じさせる。

家訓は「一両の客より十文の客を大切にせよ」。経 営理念は「おいしさの喜びをより多くの方にチリバメ ル」。

商品構成は, 名物となった焼き豚 $50 \%$, 銘柄牛の 米沢牛 $30 \%$, 弁当 $6 \%$, 惣菜 $6 \%$, 豚肉 $4 \%$ 。肉屋であ

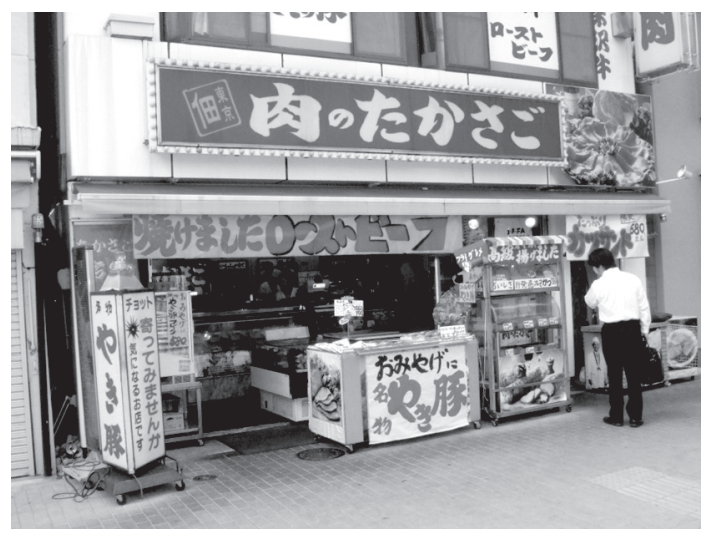

写真 1 肉のたかさご 外観 


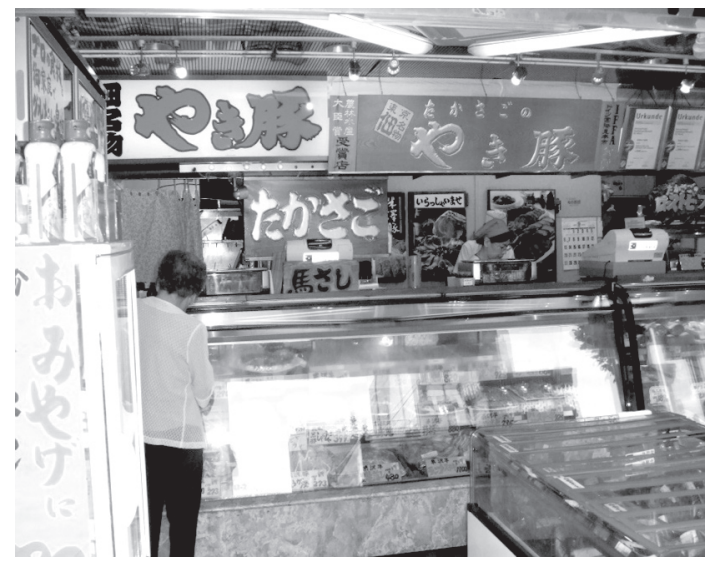

写真 2 こだわりのやき豚が大人気だ

りながら, 一般の牛肉, 豚肉の扱いはわずか。大型店 との競争を避けるため，手間をかけた，付加価值の高 いオリジナル商品に絞り込んでいる。絶品と評価され る「佃たかさごのやき豚」で知名度を上げた。豚の肩 ロースを糸で巻き, 秘伝の調味料につけて数日間寝か せ，その後，特注の鉄鍋素焼きし，さらに秘伝のたれ で煮込んだもの。ラジオ番組の通販コーナーで取上げ られ，大ブレークした。米沢牛を使った「ローストビ ーフ」も美味しく, 主力商品。「たかさごのやき豚コ ロッケ」などオリジナル商品を続々と開発している。

藤田有宏社長夫妻が磨き上げた繁盛店。売上高は約 2 億 8 千万円 $(2006$ 年当時)。従業員は約 12 人。威勢 よく元気な声と笑顔で接客。店頭の活気が伝わってく る。怙いしい食べ方や新商品の紹介など，提案型販売 を実践。店内には数多くの POP が掲示され，手書き の大きなプライスカードも目立つ。

バブル経済崩壊後は, 店が立地する佃地区には高層 マンションが増加。大型店の進出も相次いだ。激化す る競合に生き残るために，それまで重視していた飲食 店や給食への納め商法を縮小し，「付加価值の高い商 品への絞込み」,「通信販売への進出」,「インターネッ 卜販売」などで, 積極的な顧客開拓を図ってきた。経 営者の藤田氏はつねに商品開発を考え続ける, アイデ イアの塊のような方である。2006 年度の全国コンク 一ルで農林水産大臣賞受賞店。（注 6)

事例 2.お茶のおづつみ園（埼玉県春日部市） 「茶のブレンドの妙と季節感を提案する店」

街中の技や屋で，ぶらっと入りたくなるようなお

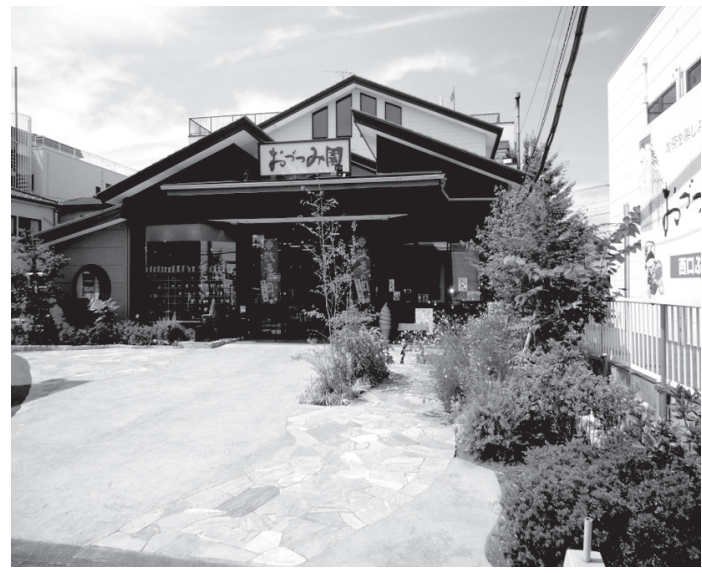

写真 3 掞茶の抢づつみ園 外観

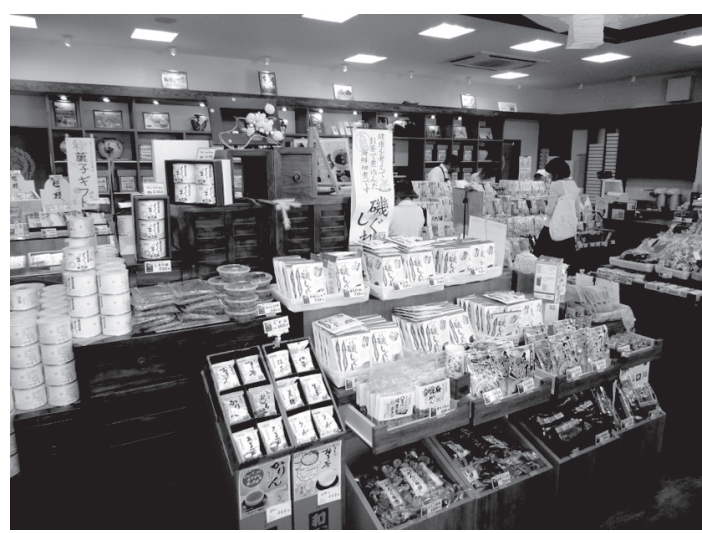

写真 4 ただ売ろうとするのではなく,

「お茶のファンづくり」に注力している

茶屋は決して多くない。いかにも擛を売っています という製造直売所のような店が多い。こんなに楽しい お茶や身近にあれば，まち全体が楽しくなる，と感じ させるお茶屋さんが「おづつみ園」である。

埼玉県春日部市の春日部駅西口から直線に延びた 「ふじ通り」の入り口, 駅から徒歩 5 分にあるのが 「おづつみ園 (ふじ通り店)」。広い通りに面した拈店 で，店が通りから 10 メートルくらいセットバックし て建てられており, 通りから眺めると, 大変立派な店 構えである。力を入れたイベント時には, 何百人もの 顧客が列をなすという。

約 36 坪の大きな売り場をもつお茶屋で，いつも何 人かの顧客でにぎわっている。お茶商品の多さが際立 つ。茶器なども充実していて, 見るだけでも楽しくな 
る。店の入り口には厨房施設があり，「オリジナル新 茶アイスクリーム」や「焼きたての花よりだんご」な どが売られている。

年商 1 億 6 千万円。従業員は約 9 人。もてなし力に 富む感じのいい販売スタッフが接客にあたっている。 同店の商品構成は，お萊 $62 \%$, ギフト商品 $12 \%$, 海 苔 $10 \%$, 菓子 $6 \%$, 陶器 $4 \%$, その他 6\%。2007 年度の 優良経営食品店全国コンクールの農林水産大臣賞の受 賞店。

経営方針は「より良い品をよりお求めやすく」, を 信念に，扮茶を通じた素敵な団らんの時間を提案し， お茶の販売を通じて地域に貢献する」。地域消費者が 参加する「荟商み教室」，「子どもお茶摘み教室」は， 毎年参加者が増え, 技茶の歴史から, お茶の種類, 緑 茶の効用や美味しい入れ方, 技茶の買い方, 食育まで 幅広い知識を伝授する機会になり，「お茶のファンづ くり」に力を入れている。技茶を売るという行為の前 に，顧客を育てる事から始めることが如何に大切かを 教えてくれる。

お茶屋で, 袋詰め商品と量り売り商品があるのは当 然だが,「おづつみ園」ではさらに「季節限定商品」 で品揃えのボリューム感と独自色を出している。春ら んらん, 水出し緑茶, 㲄だし新茶, 秋仕上げ, 賀春茶, ゆず，桜，夏みかん，黒豆をブレンドしたお茶など， 季節感を取り込んだ商品開発で, 売り場の賑わいづく りを演出している。いつも㩒りのような賑わいがあ る店になっている。(注 7)

事例 3. 酒舗まさるや（東京都町田市）

「来店客に満足を与え,リピートにつなげる」

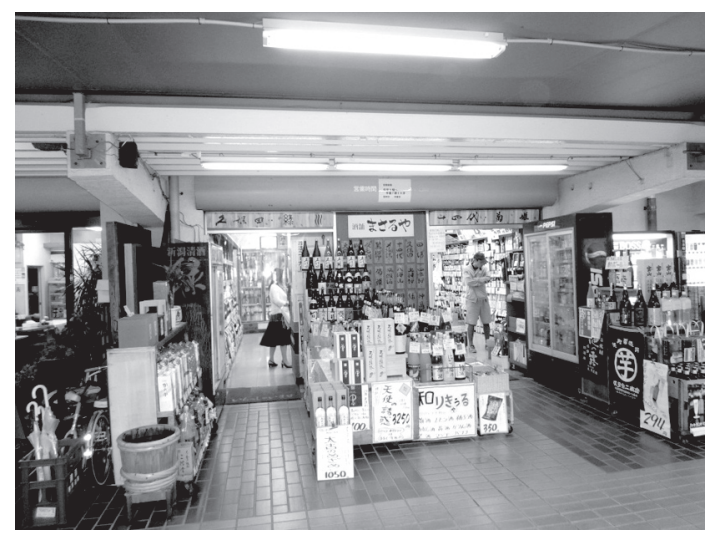

写真 5 酒舗まさるや 外観

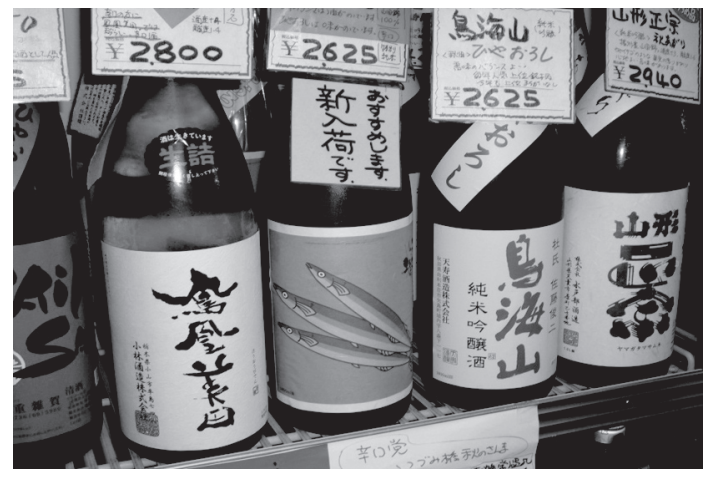

写真 6 こまめな情報提供も客からの 信頼を得るポイント

東京都町田市の約 3,000 世帯のマンモス団地, 鶴川 団地内ショッピングセンター内に立地。団地住民の高 齢化が進み, 現時点での商業立地としては決して恵ま れているとは思えない。しかも，わずか 15 坪の売り 場でありながら, 年商 6 億円を越えるビッグな酒屋, それが「酒舗まさるや」である。2005 年度の農林水 産大臣賞受賞店。

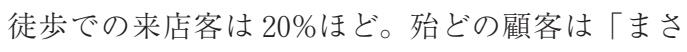
るや」での酒を購入するのを楽しみにバスや自家用車 でやってくる。わざわざ,「まさるや」の酒を求めて 遠くからやってきている。客単価は極めて高く, 平日 の客単価 5,000 円が，週末には 1 万円に倍増する。

売り上げの $96 \%$ が酒類，そのほとんどが「焼酎」 と「日本酒」に絞りこまれている。こだわりの酒専門 店と言える。スーパーやディスカウント店では真似の できない,「まさるや」ならでは品揃えが最大の集客 要因になっている。珍しい銘柄の酒が入手できれば, この店に行けば何かの発見があるとの思いで来店者が 増える。発見がある店に顧客は集まってくる。

店主自らが蔵元を訪ね歩き, 全国各地（北海道～沖 縄）のこだわりの日本酒，本格焼酎を品揃えし，他店， 競合店との差別化を図っている。日本酒は 120 銘柄, 本格燒酎 200 銘柄, 両方で 150 社との直取引を行って いる。それほど広くない店内に, 約 1,200 アイテムの 酒が並び，それぞれの酒について大型冷蔵庫や氷温冷 蔵庫での品質保持が行われている。店の中央には, 話 題商品専用の平台や試飲コーナーを設け, 情報発信に 抜かりない。

蔵元と共同開発した「オリジナル芋焼酎」の「一人 
一本の限定販売」など，創意工夫に富む。酒好きの顧 客は宝物を手に入れた気分になる。話題商品を自ら作 り出し, 業務店などに提案販売する。季節限定のお奨 め商品の提案など, つねに話題づくりを行っているの で, テレビ, ラジオ, 雑誌などでよく取上げられる。 マスコミによる宣伝効果が大きい。

豊富な品揃えで, 選ぶ楽しさがあれば, 顧客は遠く からわざわざ来店してくれる。店主のこだわりが, 商 品を通じて顧客に伝われば, ファンが増え,リピータ ーにつながる。

店内には賑やかさが漂う。チラシやPOP でこまめ に情報提供を行ない, 銘柄にもひと言コメントが添え られている。店主夫妻, スタッフ全員がこまめに酒の 情報を伝えている。

陳列と説明だけでは商品は売れない。本来の価值が 説得でき, 顧客が納得すれば, 購入という行為が完結 する。商品力だけが集客要因ではなく, 店主夫妻のも てなし力・人間力もファンを増やす重要な要素。この 面での家族経営店の強みが活かされている。(注 8)

事例 4.（株）スズノブ（東京都目黒区）

「消費者の好みに合ったお米の選び方，買い方の提供」

東京都心の南部, 東急東横線の都立大学駅から徒歩 3 分くらいの商住宅地の表通りに面した店舗が米の専 門店・「スズノブ」。間口が 6 間くらいある大きな米屋 さん。近隣の居住者のための店というより,「スズノ ブ」でのお米の買い物が好きという目的買い顧客のた めの店としての存在感をつくり出している。有名な夕 レントなども, 車で通りかかった際に, 自分の好きな 米を店頭精米してもらい, 購入して帰るという。半径

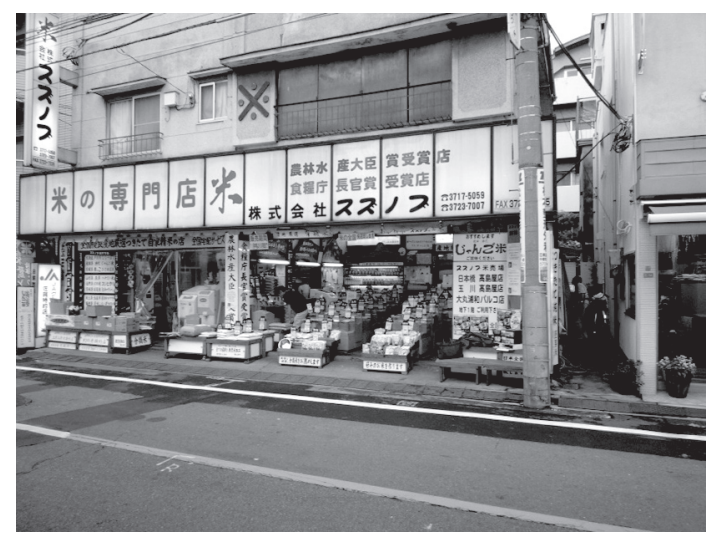

写真 7 (株) スズノブ 外観

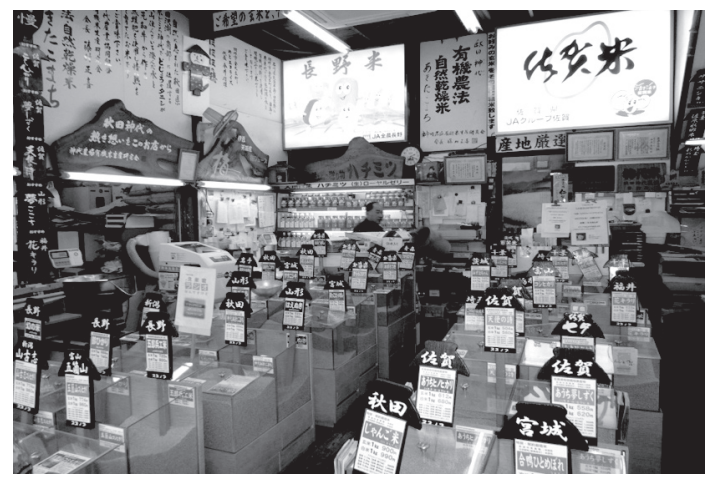

写真 8 専門店ならではの品揃えと 丁寧な顧客対応が強み

1 キロの範囲内に東急ストアーやダイエーなどがある が，大型店では専門店として米の売り方をしていない ので, 競合店とはみなしていない。「スズノブ」の商 圈は半径 15 キロ程度と非常に広く捉えている。従業 員 11 人, デパート内売り場の販売を含めて約 1 億 8 千万円の売上げ。2008 年度の農林水産大臣賞受賞店。

「拉米は消費者が選ぶもの, そのための最大限の機 会を提供する」ことを経営方針とし，実践している。 新米時には 100 銘柄, 端境期にも 40 銘柄の米（玄 米）を揃えている。お客様との対話の中で品種ごとの 味の違い, 産地ごとの味の違いなどを丁寧に説明し, その中から，拈客様の好みに合う，いくつかの銘柄を 提案し, 要望に応じた精米を行い, 購入してもらうと いう販売方法を採っている。お米のプロとしてのこだ わりから, 最も美味しい状態で食べてもらうための販 売方法として，このようなやり方に行き着いた。

お米は精米後, 出来るだけ早く食べるとおいしい。 そのために, 少量の 1 キロからの立米で販売, 最もお 勧めは 2 人家族で 2 キロが目安の売り方をしている。 好みの最適米が決まればまとめ買いを勧める。単一銘 柄米の販売だけでなく,「スズノブ」独自のオリジナ ルブレンド米にも力を入れ, 新しい味の提案も行って いる。

経営者は西島豊造氏。サラリーマンを経験後, 米穀 専門店の道に進んだ。米マイスターの資格を持つ, ま さに米博士に近い。売るだけでなく, 新たな銘柄米の 産地育成にも取り組んでいる。消費者との対話販売を 通じて, 消費者の好みや用途ニーズが分かるので, 生 産者に対しても, 新しい栽培方法や品種開発を薦め, 
時代にあったブランド米づくりとそのための農業後継 者の育成にも力を注いでいる。（注 9）

経営者のおいしいお米に対する際立った「目利き 力」がブランド・産地開発にも活かされ，食と農を結 ぶキーマンの一人に育っている。

\section{4. 顧客感動を生む出すための販売戦略}

逆風にありながら，顧客の気持ちをしっかり捉え， 確かな経営業績を上げている中小小売店の事例をいく つか紹介してきた。彼らは, それぞれが創意工夫によ って, 顧客が求めているニーズに迫る努力を続け, 顧 客づくり=顧客創造を販売戦略の軸にすえた展開で成 果を収めていることを教えてくれている。

彼らに共通する「売り方の原理」を次のようにまと めておく。

第一は, 徹底した「顧客志向」を貫いていることで ある。「店は顧客のためにある」という有名な商道が あるが，その通りのことを日々実践している。このよ うな経営理念を大切にし, 実践のための創意工夫を常 に心がけ，また実に良く勉強している経営者達である。

第二は「おいしいもの」への執拗なまでのこだわり である。プロの商人としての「目利き力」が彼らの最 大の武器となっている。したがって, 単なる低価格志 向に走らず，商品の質を大切にした品質志向経営から 離れない立場を貫き, 大型店との競争を避けている。

第三は「オリジナルの追求」である。小売業は「品 揃え業」と言われるが，生産者の作った商品を集荷し， 選びやすく，買いやすい状況を作り出すだけでは差別 化が図れない。事例で見てきた繁盛店は, 単なる品揃 え業ではなく, 他店にはない独自商品, オリジナル商 品も開発し, ここしかないというオリジナル性も重要 な集客要素になっている。

第四は「対話販売」と「説得販売」が功を奏してい る。説明抜きで大量に販売するには, 商品のブランド 力を高め, セルフ方式の陳列販売が有効であるが, 顧 客一人ひとりと対話し, 商品の持ち味をしっかりと伝 えながら売ることが出来るのが専門小売店の強みであ る。

モノが売れない消費不振が長く続くと, 構造不況と の認識が拡がり, 売れないことを景気, 不況のせいに してしまうことが多い。売れない理由を環境変化とい う外部要因に求めないで, そういうときこそ, 顧客が
感動するくらい高いレベルの価值提供が本当にできて いるかどうかの内部チェックできる企業文化が必要で あろう。厳しい環境に勝ち抜く販売戦略に磨きをかけ, 企業力を高める絶好のチャンスにいかすべきであろう。

筆者は, 顧客の感動を勝ち得る小売サービス経営の 基本要素を次のように考える（注 10）。

(1) 経営理念と共感力

(2) 店舗力 $\times$ (3) 商品力 $\times$ (4) 人間力 (接客, ホスピタリティ)

(5) 情報力

このような経営資源を最大限に活かした過程から顧 客感動満足が創られ, 企業業績が上がる。感動満足と は,「顧客の期待を超える価值の提供」と定義してい る。小売サービス業の販売戦略に秘策はない。満足感 が高ければ, 必ず顧客は戻ってくる。満足感を創り出 すために, 価值創造プロセスを高める以外に有効な方 法はない。

最後に, 摇れ動きやすい消費者を常連客, ファン, 支持者になってもらうための「きずなづくり」に欠か せない経営観を提示しておきたい。(1)売れる店は顧客 のための「購買代理店」という認識が大切。(2)小売業 はモノの「使用価值提供業」。(3)販売は顧客との「共 感づくり」「きずなづくり」。(4)販売は売る人の「人間 力・もてなし力」の反映。(5)小売サービス業は「生活 の豊かさ創造業」。売るための攻めの販売戦略を実践 する上で, 参考にして欲しい。

\section{おわりに}

小売店を念頭に置きながら, 売れない時代の販売戦 略, 攻めの販売戦略とは何かを考えてきた。モノを造 るメーカーの立場と消費者にモノとサービスを売る立 場では, マーケティングの展開に微妙な違いがある。

生産者と消費者とをつなぐ大切な役割を担う小売業, その中でも役割が埋没しかねない状況にある中小小売 業の立場から, 存在感を発揮している小売業の販売戦 略を俯瞰してみた。「喜んで, 扮客様に感謝していた だけるようなことを実践しながら，自らが成長してい く」。自分の道を, ぶれずに, 使命感を持って進めば, 必ず小売店としての存在理由が生まれてくる，という メッセージを贈って, 本稿をおわりたい。 〈西武文理大学 名誉教授〉 
注 1. 本表彰事業の趣旨は, 各地で頑張っているお店 や商店街を表彰し，その経営ノウハウを公開して もらうことによって, 事業全体の活性化を図るこ とを目的としている。応募事業者の中から, 農林 水産大臣賞, 農林水産省食料産業局長賞, 日本経 済新聞社社長賞, (財) 食品流通構造改善促進機 構会長賞の各受賞店を決定し，公表を行っている。 注 2. 平成 23 年度の受賞式が平成 24 年 2 月に行われ, 農林水産大臣賞が 3 店, 農林水産省食料産業局長 賞が 6 店, 日本経済新聞社社長賞が 3 店, (財) 食品流通構造改善促進推進機構会長賞 2 店の受賞 が決まった。大臣賞には, 株式会社丸八食品（愛 知県, 食肉小売店), 有限会社木川屋商店 (山形 県, 酒小売店), かごしま屋（福岡県, 酒小売 店）の 3 店が選ばれた。受賞店の概要は（財）商 品流通構造改善促進機構ホームページにて公表さ れている。

注 3. 受賞店の概要は, 毎年, 「食料品小売店等経営 ノウハウ集」として公表されている。

注 4. 経済産業省「平成 21 年版 我が国の商業」

注 5. 研究会報告書「競争と協調の中で社会と共に進 化するコンビ二」が「社会インフラとしてのコン ビニエンスストアのあり方研究会」から出された。
平成 21 年 4 月。

注 6.「食料品小売店等経営ノウハウ集・第 16 集」

(財) 食品流通構造改善促進機構, 平成 19 年 1 月 26 日発行）より引用。中で使っている数字もノ ウハウ集より, 当時のものを使用した。以下の事 例も同様であることを断っておく。

注 7.「食料品小売店等経営ノウハウ集・第 17 集」(平 成 20 年 1 月 24 日発行）より引用。

注 8.「食料品小売店等経営ノウハウ集・第 15 集」(平 成 18 年 1 月 26 日発行）より引用。

注 9.「優良経営食料品小売店等全国コンクール受賞 店の概要」(平成 21 年 1 月 23 日発行) より引用。 注 10. 小山周三『サービス経営戦略』(NTT 出版,

平成 17 年)

注 11 . 本稿は平成 22 年 2 月に入間市商工会にて行っ た講演会『今, 小売業が生き残るために出来るこ と, やれることはなにか? 』の講演資料を基に執 筆したもので, 元気のいい小売店の販売戦略から 学び取れることを筆者の視点でとりまとめたもの である。本稿で取上げた事例は筆者自身も訪問・ 視察しており，掲載写真も筆者が撮影したものを 使用した。 